\title{
Traditional Veterinary Medicine of Indigenous and Non- Indigenous Campesinos of the Southern Andes: An Ethnoecological Approach
}

\author{
Fernanda Olivares \\ Universidad Austral de Chile

\section{Carla Marchant} \\ Universidad Austral de Chile \\ José Tomás Ibarra ( $\nabla_{\text {jtibarra@uc.cl ) }}$ \\ Pontificia Universidad Católica de Chile
}

\section{Research Article}

Keywords: Ethnoveterinary medicine, local ecological knowledge, medicinal plants, animal production

Posted Date: January 18th, 2022

DOI: https://doi.org/10.21203/rs.3.rs-1266099/v1

License: (c) (i) This work is licensed under a Creative Commons Attribution 4.0 International License. Read Full License 


\section{Abstract}

Background: In an ethnoecological framework, traditional veterinary medicine comprises knowledge, practices, and beliefs about farm animals. Its study serves to offer ecologically and culturally appropriate strategies for management of the animals and their health in a context marked by the increased use of allopathic medicine, socio-environmental degradation, pollution, and climate change. In this study, we use an ethnoecological approach to document the ethnoveterinary knowledge, practices, and beliefs that Mapuche and non-Mapuche campesinos in the southern Andes have about the management of animals and their health. In addition, we investigate the main factors influencing the current use of traditional veterinary medicine.

Methods: In January-March 2021, we undertook participant observation and conducted 60 semi-structured and informal interviews with Mapuche and non-Mapuche campesinos from the Pucón and Curarrehue municipal districts in the southern Chilean Andes.

Results: On animal management, we identified a set of knowledge about climatic conditions that is the basis of 14 practices related to animal production, feeding, and reproduction. On health management, we recorded knowledge about 30 plant species, grouped into seven categories. The highest informant consensus factors were for the categories of wounds and parasites. The main treatment preparation practices are decoction (42\%) and oral administration (77\%). We identified a system of beliefs with close ties to the Mapuche cosmovision, based on respect and connection with the different manifestations of nature. We found that the growing use of allopathic medicine, the processes of reduction and change in the structure of land ownership, and climate change are the main factors in the current lower use of traditional veterinary medicine.

Conclusion: Our results reveal the presence of ethnoveterinary knowledge, practices, and beliefs that are safeguarded by Mapuche and non-Mapuche campesinos in the southern Andes. However, their use is under threat, making it imperative they are documented and visibilized since they provide new perspectives for the development of bioculturally diverse and sustainable animal production.

\section{Introduction}

In an ethnoecological framework [1], traditional veterinary medicine (TVM) or ethnoveterinary medicine comprises the different knowledge, practices, and beliefs that human groups have about raising farm animals. Ethnoveterinary studies start from the assumption that, over time and through observation, trial, and error, campesinos and indigenous peoples have developed their own concepts and techniques for managing animals and their health [2,3]. TVM is important in human communities whose economic livelihood and food depend on raising domestic animals because it offers viable alternatives for the animals' care and health, using local resources and without additional monetary cost. Moreover, it has a cultural and symbolic component that is part of the identity of the different peoples [4-7].

Research on TVM is geared to the development of ecological and socioculturally appropriate strategies that consider animal and human well-being $[2,4,8]$. Most research focuses on ethnoveterinary knowledge about using plant species to prevent or cure diseases in domestic animals. In Pakistan, for example, 474 plant species with therapeutic potential in animals have been identified [6]. Similarly, the use of 139 plant species to treat animal diseases has been reported in South Africa [9]. In addition to this knowledge, there are also practices and systems of beliefs that need to be investigated to achieve a comprehensive understanding of animal production, considering aspects of animal management together with its sociocultural particularities [1]. In the Austrian Tyrol, for example, preventive feeding with functional and medicinal plant species has been identified as a prophylactic ethnoveterinary practice for maintaining animal health [10]. In Los Altos de Chiapas in Mexico, the belief system of Tzotzil women considers sheep sacred and their sacrifice and consumption are forbidden, giving their breeding a meaning beyond its production aspects [11].

Various global phenomena such as changes in ways of life, the intensification of climate change, socio-environmental degradation, pollution, the expansion of agrarian modernization, and the adoption of allopathic veterinary medicine pose a threat to the current and future use of TVM $[4,7,12,13]$. For example, in livestock farming communities in Zimbabwe, 
ethnoveterinary health knowledge about eliminating external parasites in cattle is considered only in the absence of allopathic products [14]. Similarly, in Los Altos de Chiapas, Mexico, the use of ethnoveterinary knowledge and practices is threatened due to the impact of population growth and increasing soil erosion on the availability of therapeutically effective plant species [11]. In Catamarca, Argentina, the increasing and priority use of allopathic medicine has been cited as posing a risk of the disappearance of ethnoveterinary knowledge and practices [15].

The southern Chilean Andes have historically been inhabited by the Mapuche people, who were sovereign and independent from the Chilean nation state until the end of the nineteenth century [16,17]. In this territory, the human-animal bond dates back to pre-Hispanic times, starting with the hunting of wild birds and the south Andean deer (Hippocamelus bisulcus) and the rearing of chilihueques (Lama guanicoe) and chickens (Gallus gallus) before the Mapuche adopted and began to breed the cattle, sheep, horses, and pigs introduced by the Spanish in the sixteenth century [16,18-21]. The fertile proliferation of the introduced livestock led to the disappearance of chilihueques in the seventeenth century and, in the eighteenth and nineteenth centuries, livestock farming became the mainstay of the Mapuche economy [16-19]. In parallel, different accounts from before the nineteenth century report the use of species of trees, shrubs, and herbs for treating human and animal diseases [20-22]. The military occupation of the Mapuche territory by the Chilean nation State at the end of the nineteenth century brought with it a drastic process of dispossession of land, leading to the reduction and deterritorialization of the Mapuche $[17,23]$. This, in turn, meant the end of extensive livestock farming and the adaptation of agrosilvopastoral activities to smaller spaces $[16,23]$. At the same time, the territory was colonized by migrants from the rest of Chile and overseas who, once settled, used the land for other agrosilvopastoral activities, including particularly wheat farming and forestry $[26,27]$. In the late twentieth century, in a territory by then shared by Chileans, foreigners and the Mapuche, the Chilean state promoted a strategy of productive and economic modernization for the Mapuche and non-Mapuche campesino sector [25,26]. This involved the promotion and/or transfer of agricultural and livestock technical advice through extensionist government programs. They included the introduction in 1996 of the Local Action Development Program and, in 2009, the Indigenous Territorial Development Program, both of which remain in operation [26,27].

Despite the different historical and contemporary processes of profound change that have occurred in the southern Chilean Andes, this territory has acted as a refuge for knowledge about agrosilvopastoral practices, safeguarded by both Mapuche and non-Mapuche campesinos. [28,29]. Specifically, in the case of studies of the traditional veterinary medicine practiced there, some research has addressed it from another standpoint. For example, there are studies that indicate the existence of constant dialogue between agricultural activities and the raising of domestic animals that favors ecological interaction, based on the use of animal manure to fertilize home gardens and grassland, as well as the use of animals in cropland to control pests [2931]. In the case of medicinal plant species, different studies have looked at their use in humans [32-35]. Moreover, studies of TVM have concluded that the repertoire of plant species for human use may also be used in animals [12,37]. Together with historical records about the use of plants and animal management practices, this suggests the current presence of potential ethnoveterinary knowledge, practices, and beliefs $[20,21]$.

This study seeks to answer the following questions: What ethnoveterinary knowledge, practices, and beliefs about the management of animals and their health are found among Mapuche and non-Mapuche campesinos in the southern Chilean Andes? What are the main factors influencing their current use? To this end, we use an ethnoecological approach $[1,37]$ to document ethnoveterinary knowledge (corpus), practices (praxis), and beliefs (kosmos) about animal management, understood as the different activities involved in caring for farm animals, and ethnoveterinary knowledge (corpus), practices (praxis), and beliefs (kosmos) about health management, understood as the different plant species known for the prevention and treatment of diseases in these animals. Finally, we identify the main perceived factors that influence current use of traditional veterinary medicine by Mapuche and non-Mapuche campesinos in the southern Chilean Andes.

\section{Methodology}

\section{Area studied and ethnographic context}


The study was carried out in the Pucón and Curarrehue municipal districts, located in the Andean part of the Araucanía Region $\left(39^{\circ} \mathrm{S}\right.$ and $\left.71^{\circ} \mathrm{W}\right)$ in the southern Chilean Andes (Figure 1). The area has a temperate climate, with an average annual rainfall of 2,556 mm. January and February (summer) are the warmest months, with an average temperature of $15^{\circ} \mathrm{C}$ in Curarrehue and $16^{\circ} \mathrm{C}$ in Pucón. July and August (winter) are the coldest months when the temperature averages $4.9^{\circ} \mathrm{C}$ in Pucón and $1.7^{\circ}$ $\mathrm{C}$ in Curarrehue. The Pucón municipal district has 28,523 inhabitants of whom $36 \%$ live in rural areas and $29 \%$ are Mapuche [38], while the Curarrehue district has 7,489 inhabitants of whom $70 \%$ live in rural areas and $67 \%$ are Mapuche [38]. The territory has examples of large, medium, and small-scale livestock production, including cattle (Bos taurus), sheep (Ovis aries), goats (Capra hircus), pigs (Sus scrofa), horses (Equus caballus), and/or poultry (Gallus, Meleagris gallopavo, and Anas platyrhynchos domesticus) [38]. In the small farms of Mapuche and non-Mapuche campesinos, different traditional agrosilvopastoral practices are used to produce for family consumption and/or sale as well as for cultural and symbolic purposes $[28,29,39]$. Mapuzungun $(\mathrm{mapu}=$ land; zungun = speech) is the Mapuche language, spoken by some elderly people and adults but, for most of the territory's inhabitants, Spanish is their first language and they know only a few words of Mapuzungun [39].

\section{Methodological design and fieldwork}

The research used a mixed approach based on quantitative and qualitative methodologies [40]. The fieldwork, which included participant observation and semi-structured and informal interviews, took place in January-March 2021. Interviewees were selected using the snowball sampling method $[41,42]$. In all, there were 60 semi-structured interviews with Mapuche and nonMapuche campesinos from Pucón ( $n=30)$ and Curarrehue $(n=30)$ (Annex 1), conducted after the signing of a letter of free and informed consent, as well as 20 informal interviews. Mapuche and non-Mapuche campesinos were grouped together since the latter share the bond of having been born in the territory and of living and working there. Moreover, their agricultural systems incorporate and resemble the traditional Mapuche system [28,43]. In the first part of the interview, information was obtained about interviewees' socio-productive characteristics before broaching the knowledge that structures livestock farming (corpus) and ethnoveterinary animal management practices (praxis) in the different types of livestock farming. The names of the plant species and parts used to treat diseases in animals (corpus) were then documented, together with the methods for preparing and administering the treatments (praxis). Information was also collected about the system of beliefs (kosmos) implicit in both animal and health management. Finally, interviewees were asked about the main factors influencing current animal and health management practices. The semi-structured interviews were complemented with informal interviews and participant observation [42], which were recorded in field notes.

\section{Data analysis}

The interviews were transcribed and subjected to thematic content analysis [44] using the Atlas.ti software. Specifically in the case of animal management, the corpus was also classified into categories of knowledge [37]: astronomical, related to the phases of the moon; geophysical, related to the lithosphere (soil types), the hydrosphere (water cycles), and the atmosphere (winds, clouds, climates); biological, related to the use of plants, animals, fungi, and microorganisms; and eco-geographic, related to vegetation and landscapes. The closed interview questions were coded in an Excel spreadsheet for descriptive analysis of frequency, mode and mean with the SPSS program version 23. Additionally, in the case of health management, the informant consensus factor (ICF) was calculated [45] for the different disease categories identified:

$\mathrm{ICF}=($ nur-nt) $/($ nur-1)

where: nur = number of reports of use in each category; nt = number of species used by category.

The product of this factor fluctuates between 0 and 1, with results close to 1 indicating that the plant species of the group are used by a large proportion of people, suggesting that they are of greater cultural interest. Finally, the results obtained from the quantitative and qualitative analysis of the semi-structured interviews, informal interviews, and participant observation were integrated in order to answer the research questions [40]. 


\section{Results}

\section{Socio-productive characterization of Mapuche and non-Mapuche campesinos}

A total of 60 campesinos (48 women and 12 men) were interviewed of whom 76.7\% were Mapuche and 23.3\% were nonMapuche. Out of the interviewees, $58.3 \%$ were seniors ( $\geq 60$ years), $40 \%$ were adults ( $30-59$ years), and $1.7 \%$ were young people (15-29 years). Three-quarters (75\%) were receiving advice through government programs. The area used by interviewees for their different agrosilvopastoral tasks averaged 9.8 hectares (mode of $2 \mathrm{ha}$ ). The most frequent types of production - that is, the animals farmed by the largest number of campesinos interviewed - were poultry ( $96.7 \%)$, sheep (93.3\%), and cattle (65\%) while horses (33.3\%), pigs (28.3\%), and goats $(8.3 \%)$ were less common. As regards the members of the family nucleus responsible for each activity, women were mainly in charge of poultry $(72.9 \%)$, goats (60\%), and sheep (44.6\%), for which spaces around the home are used during the day and, at night, barns, sheds, or coops (Figure 2). Men were primarily responsible for horses (90\%), cattle (43.6\%), and pigs (52.9\%) (Figure 2). Horses are kept in areas around the home because they serve as a means of transport while cattle are raised in grazing sites in the mountains, on rented grassland, and on summer pastures (movement of the herd to mountain areas during the summer for grazing and mating). Pigs are raised both near the home and further away.

\section{Ethnoveterinary knowledge and practices for animal management}

Our results indicate the existence of a body of knowledge or corpus of the following types: atmospheric (temperature, photoperiod, winds, periods of rain); astronomical (lunar phases); biological (plant and animal species); eco-geographic (landscape and vegetation units); and about the hydrosphere (water courses) and the lithosphere (soil characteristics). This corpus, grouped into the different seasons of the year, is used to plan 14 practices or praxis related to the raising of cattle, sheep, goats, horses, pigs, and poultry (Table 1). The main practices mentioned by interviewees are described below.

\section{TABLE 1}

Supplementary feeding. This praxis is organized based on the corpus represented by lower grassland productivity, snow on the mountains, and the availability of shrubs and/or trees for feeding animals. Its frequency was measured as the number of mentions of the practice by type of production species. It is employed by $94.9 \%$ of the campesinos who breed cattle (frequency $=37$ ), by $98.2 \%$ of those who breed sheep (frequency $=55$ ), and by $100 \%$ of those who breed horses (frequency $=20$ ) and goats (frequency $=5$ ). It consists of feeding cattle, sheep, horses, and goats with bales of fodder, harvested on the same property or purchased from neighbors and/or external suppliers during the summer. Supplementary feeding with grains and/or concentrate is used mainly for horses, pregnant ewes, and thin cattle. These supplements are acquired from external suppliers and/or as benefits for campesinos registered with government programs. Interviewees indicated a preference for supplementing with oats, rather than concentrate, given the versatility of oats as feed for different species as well as its effect on the animals, as reported by one interviewee: "The concentrate makes the sheep's babies develop a lot and then they have trouble giving birth; the same happens with cows, that's why oats are better" (man, 74 years). We also identified practices applied in specific cases. For example, when campesinos do not have the economic resources to buy feed, they collect bamboo (Chusquea spp.) and branches of the palo trébol tree (Dasyphyllum diacanthoides). Another practice mentioned was that, when nursing ewes are very thin and have difficulty producing milk, they are given chupilca, a drink made of water, wheat flour, and sugar. As a complement, salt is also added to cattle and sheep feeders, although some campesinos prefer to use mineral blocks, obtained through government programs and/or from agricultural suppliers.

Sheep shearing. The corpus related to the presence of the seeds of the trune (Acaena ovalifolia) and pimpinela (Acaena pinnatifida) is used to plan the shearing season by $17.9 \%$ of the campesinos who raise sheep (frequency $=10$ ). They schedule this praxis for late November or early December, a timing that prevents the seeds from adhering to the wool and rendering it unusable for spinning and weaving, as mentioned by one interviewee: "November is best for shearing because the pimpinela doesn't stick to the wool. Because when the pimpinela is mature, the wool can't even be spun; it's all lost" (woman, 70 
years). During this period, higher temperatures also cause heat stress in the sheep, making them eat less and affecting their well-being and productivity.

Summer grazing. The corpus represented by higher temperatures, a decrease in the productivity of grasslands, reproductive cycles and vegetation units in mountain landscapes organizes this transhumance praxis. It is used by $41 \%$ of the campesinos who farm cattle (frequency $=16$ ). The animals are left on their summer pastures until April-May when they are brought down to winter pastures or places closer to the owner's home. During the summer, the herd is visited intermittently by its owners or those responsible for it, who are mostly men. Summer grazing means that the animals have access to different forage species, unlimited water sources, and trees for shelter, as indicated by one interviewee: "The animal grows healthier in the mountains than anywhere else... because it drinks good water... when the calves are brought down, they look like fat little barrels, because the cow produces good milk, because she eats good herbs" (man, 85 years). In their summer grazing, the animals have access to functional forage - or, in other words, food that is perceived as positive for animal health and yield - as well as medicinal forage, that is, food eaten while foraging that prevents and cures diseases [10]. The campesinos perceive that the animals prefer to graze in mallínes, a type of wetland meadow, where they have access to functional types of forage (Figure 3 ). The medicinal forage mentioned includes paramela (Adesmia boronioides) and quinchamalium (Quinchamalium chilense), herbs with therapeutic properties that are part of the Mapuche medicinal repertoire.

Castration. This practice consists in removing the testicles of cattle destined to become steers or oxen and of pigs for fattening. The corpus related to the presence of a waning moon determines the appropriate moment for this praxis and is taken into account by $41 \%$ of the campesinos with cattle (frequency $=16$ ) and $35.3 \%$ of those with pigs (frequency $=6$ ). The waning moon is associated with a decrease in body fluids, as indicated in the following account: "When the moon is finishing its waning, the animals are castrated, because they bleed less; when the moon is waxing, they bleed a lot" (woman, 73 years). In this way, hemorrhages are avoided and clotting and healing are facilitated.

Sheep mating. This corpus is related to the decrease in daylight hours, the characteristics of sheep's reproductive cycle, and lower temperatures. Mating, using a ram previously separated from the flock, takes place in April and/or May, as indicated in the following account: "I learned from the elders who separated the ram, they mate in early May so birth is in October" (man, 75 years) (Figure 3). The separation of the ram is practiced by $48.2 \%$ of the campesinos with sheep (frequency $=27$ ), scheduling lambing for a time of year when more forage is available and the weather is better.

Putting ash in chicken coops. This praxis is used by $45.8 \%$ of campesino women who keep poultry (frequency $=27$ ). It consists of putting piles of ash from wood-burning stoves or fireplaces inside the chicken coop, as explained by the following interviewee: "I put ash in the chicken coops so they roll in it and get rid of bed bugs" (woman, 68 years). This corpus is related to the presence of different hematophagous arthropod-type ectoparasites such as the bed bug (Cimex lectularius) and the red mite (Dermanyssus gallinae) that infest birds, causing economic losses due to a reduction in egg laying, weight loss in the chickens, and, in severe cases, even their death.

\section{Ethnoveterinary knowledge and practices for health management}

Our results identify a corpus represented by 30 plant species from 24 botanical families with therapeutic potential for preventing and treating diseases in cattle, sheep, goats, horses, pigs, and poultry. In most botanical families, only one species was identified, except for Asteraceae, Rosaceae, Lauraceae, Proteaceae, Santalaceae, and Cunoniaceae of which there are two species (Table 2). The species identified are mostly of native origin (21 species; 70\%; Table 2). The main group are herbs (15 species; $50 \%$ ), followed by trees (10 species; $33.3 \%$ ) and shrubs (5 species; $16.7 \%$; Table 2 ). The plant parts most frequently mentioned are leaves $(52.9 \%)$, roots $(14.7 \%)$, bark $(11.8 \%)$, seeds $(8.8 \%)$, branches $(5.9 \%)$, bulbs $(2.9 \%)$, and stems $(2.9 \%)$.

\section{TABLE 2}

The techniques used to prepare the treatments are decoction (41.9\%), crushing (23.3\%), infusion (14\%), direct administration $(11.6 \%)$, drying leaves $(2.3 \%)$, heating stems $(2.3 \%)$, soaking seeds $(2.3 \%)$, and burning tree bark (2.3\%). For decoction, 
infusion, and soaking, the solvent used is water to which, depending on the disease in question, ash, soot, sugar, and/or salt may be added. The preparations are administered orally (76.5\%), topically (17.6\%), ophthalmically (2.9\%), or as smoke (2.9\%).

We identified seven categories of symptoms and diseases (Table 3). The systemic infections category groups together diseases caused by different etiological agents. Their symptoms are a fever and general unwellness, with the latter also referred to as achaque or tristeza (sadness) in the animal. The diarrhea category includes conditions commonly known as empacho (indigestion) or churreta (the runs). Placental retention is the failure to deliver the afterbirth and is also known locally as 'no botar pares'. The parasites category includes infestation with internal and external parasites while the mastitis category refers to the symptoms associated with udder inflammation in ruminants. Finally, the keratoconjunctivitis category includes diseases that cause blindness or cloudy eye in ruminants. The categories of wounds (ICF $=0.91)$ and parasites $($ ICF $=0.90)$ have the highest values, suggesting common use of the species included in these groups, due probably to their cultural importance and bioactive potential (Table 3).

\section{Ethnoveterinary system of beliefs}

We identify a system of beliefs closely linked to the Mapuche kosmos, which is expressed in participation in the Nguillatun ceremony as well as in the daily way of inhabiting the territory. The Nguillatun (Nguillatu = ask; $\mathrm{n}=$ action) is a supplication held every two to three years by Mapuche communities in which a connection with the Wenu Mapu (highlands) is established. In this way, dual energies are balanced through supplication and thanksgiving to Ngentechen (God), begging for different living manifestations, as reported by an interviewee: "We ask for everything, for health, the harvests, for this illness that is around, for the animals" (woman, 81 years). This reflects an integrative vision that takes into account the welfare of all the beings that inhabit the earth, maintaining balance and, therefore, well-being. Despite the importance attributed to the Nguillatun, not all the Mapuche campesinos interviewed participated in it, due to factors such as loss of the tradition because of the death of ancestors, distance from the places where the ceremony takes place, and, in some sectors, a larger proportion of young people, who do not identify with it. Non-Mapuche campesinos living in neighboring sectors indicated that they were aware of the ceremony but did not take part in it because they did not feel Mapuche. The presence of Catholic and Evangelical churches in the territory indicates the existence of a system of beliefs linked to these religions. Members of Mapuche communities may identify with Catholicism while remaining Mapuche. By contrast, Evangelical churches seek to replace traditional Mapuche beliefs and ceremonies [46].

When referring to their way of life, Mapuche campesinos recount how, in their daily praxis, they ask permission from the $n g e n$ (the caretakers or owners of places) when, for example, they go into a wood or up a mountain, when livestock is going to be moved, or when crossing an estuary. This practice was described by an interviewee: "Because when you enter land that you have never stepped on before, you ask for permission, or when you enter a small stream and go by that stream, you ask for that water and wet your hand because all those things have their ngen, that's why one has to ask permission. One says, 'I am going to enter this land today and may all the ngen accompany me' and you enter calmly' (woman, 71 years). This corresponds to the $\mathrm{Az} \mathrm{Mapu} \mathrm{(customs} \mathrm{of} \mathrm{our} \mathrm{land)} \mathrm{or} \mathrm{the} \mathrm{norms} \mathrm{that} \mathrm{order} \mathrm{reciprocity} \mathrm{or,} \mathrm{in} \mathrm{other} \mathrm{words,} \mathrm{the} \mathrm{space} \mathrm{where} \mathrm{it} \mathrm{is}$ possible to achieve exchange in order to maintain the dual balances existing in the kosmos and, therefore, harmony [47]. In this way, the Az Mapu establishes a framework of behavior that is inextricably linked to how animals are raised and is the kosmos dimension of ethnoveterinary knowledge and practices.

In the case of health management, it is important to bear in mind that, for the Mapuche, the different plant species are manifestations of life that have a pullu (soul) and are governed by a set of rules that determine their use because each plant has a higher owner [35]. In this way, the Az Mapu remains present in ethnoveterinary knowledge and practices, establishing principles based on asking for permission and reciprocity when using a plant species, as described by an interviewee: "One asks for permission, one says 'excuse me' because I'm going to take this remedy and hopefully it goes well ... permission is asked for all the remedies that one looks for in the countryside ... you have to have faith that it will do you good; otherwise, it won't do anything" (woman, 71 years). Other interviewees also mentioned the importance of having faith in the effectiveness of the plant species and planning for which illness it is to be used. We observed that, for non-Mapuche campesinos, the praxis of obtaining a plant species, for use either in humans or animals, takes place in a framework of respect and trust. This can be 
attributed to the deep-rooted traditions around plant species that exist in the territory where practices are shared, due to the proximity of farms, the human relationships that are generated, and the distance from shopping centers and/or medical centers.

Finally, the notion of kosmos is behind the Mapuche conception of illness, as expressed by one interviewee: "That we get sick, that animals get sick, is something natural, it's something that's included in our nature" (woman, 53 years). It is important that illness is seen as part of the inherent duality of being on earth. In this way, both the use of plant species and the Nguillatun contribute to living and acting in equilibrium, in a context marked by constant destabilizing influences. However, this does not preclude attributing illness in animals to human behavior in the form of polluting praxis such as the accumulation of waste and the use of agrochemicals, a perception shared by both Mapuche and non-Mapuche campesinos.

\section{Factors influencing current use of traditional veterinary medicine}

Our results indicate that factors associated with agricultural modernization processes, reductions and changes in the structure of land ownership, and climate change are affecting current use of traditional veterinary medicine (TVM). They imply the assimilation of new practices and hybridization as well as TVM's adaptation, maintenance, and/or loss. In the case of animal management, modernization is visible in the introduction of technological packages of hybrid seeds and chemical and/or agrochemical fertilizers. These products, introduced through extensionist government programs, are intended to establish pastures for animal supplementation and field clearing as recounted by one interviewee: "INDAP [an extensionist government program] brought the chemicals. We were implementing a project and it was going to buy so much seed and so much fertilizer... but that was the evil that was put in the ground, because now it doesn't produce natural grass, just weeds" (woman, 55 years). Agricultural modernization is also seen in the introduction and assimilation of new energy feed for animals such as concentrate. Interviewees talked about how feed acquired from agricultural suppliers is produced with conventional methods that use technological packages: "The old men of the farm apply so much fertilizer and chemicals so that the land produces all it can. And it turns out that the grain comes with a lot of chemicals. And, with that, you feed the animals, you eat the animals, and it gets to you" (man, 46 years).

In the case of health management, agricultural modernization is reflected in the introduction and assimilation of allopathic medicine. In our study, 70\% of interviewees were using exclusively allopathic management in the form of antiparasitics, vaccines, antibiotics, and vitamins; $14 \%$ were applying mixed management, combining TVM with allopathic management; $11 \%$ were using only TVM; and $5 \%$ were not using any treatment at all.

Reductions and changes in the structure of land ownership are influencing the expression of animal and health management. The more limited space available for keeping animals has led to a reduction in the different species of animals and, in some cases, their elimination, as reported by one interviewee: "Almost no one here has cows now. Because people sold land and it got smaller... if you walk down, you see houses on the different sides... there isn't space for raising [animals] any more" (woman, 70 years). When it is necessary to eliminate cattle, the new generations lose a space for praxis and, with it, the associated ethnoveterinary knowledge, practices, and beliefs. In addition, the change in the structure of land ownership restricts rotation and the movement of livestock between the mountains and grasslands traditionally used for grazing, increasing dependence on external sources of feed in the form of rented pastureland and/or the purchase of fodder.

In health management, changes in the structure of land ownership have impeded access to places where therapeutic plant species grow, as explained by one interviewee: "Now I don't go to collect the palo santo I used to collect higher up, without any restrictions ... I would go through a couple of fences and that was it ... no longer, because there are locked gates, you can't go into someone else's place" (woman, 53 years). Similarly, anthropic intervention of rivers and the urbanization of rural areas have led to the disappearance of plant species used to treat animals. For example, the species known as cow grass (Juncus procerus) was widely used to treat placental retention in ruminants, but is now difficult to find because of the construction of roads where these plants grow. 
In the case of animal management, climate change is also affecting the productivity of the fields used to feed animals, as indicated by one interviewee: "It rains less and that is greatly affecting people's way of life, of working the fields, sowing, because if there is no irrigation and it doesn't rain, you can't sow ... the grass doesn't grow" (woman, 53 years). The decrease in rainfall and the effect on growth of the grass reduce fodder availability, with results that include the assimilation of new animal feeding praxis and hybridization and, in extreme cases, a reduction in livestock. Similarly, in the case of health management, climate change is affecting the availability of therapeutic plant species as reported by one interviewee: "The climate itself must have hidden some medicines. There are many medicines that have disappeared... And these mountain ranges had them" (woman, 69 years). Interviewees also noted that high temperatures make animals more prone to diseases and external parasitisms due, for example, to an increase in the presence of horn fly (Haematobia irritans) in cattle.

\section{Discussion}

This study examined how the links between campesinos, domestic animals, and their environment generate traditional veterinary knowledge, practices, and beliefs that are constantly being adapted and are, therefore, able to support different forms of livestock farming. Preliminarily, we identify perceived socio-environmental changes that are affecting these links, including agricultural modernization, reductions and changes in the structure of land ownership, and climate change. These changes lead to the persistence and/or loss of traditional veterinary medicine (TVM) as well as the assimilation of new praxis and hybridization.

On animal management, we show how a critical winter season in production terms determines supplementary feeding and animal shelter practices. This makes the campesinos more receptive to new practices, related principally to the modernization promoted by government programs. These new praxis are incorporated through processes of assimilation and hybridization $[34,48]$. A similar case is seen in campesino communities in Argentine Patagonia where government programs are introducing new horticultural practices, giving rise to processes of innovation, hybridization, and/or the loss of traditional horticultural knowledge [49]. The assimilation of new practices and hybridization do not necessarily preclude the use of TVM; rather, they correspond to a process of constant evolution and adaptation to changing environmental and socioeconomic conditions [50]. Around the world, indigenous peoples and local communities are resorting to a series of responses to the impacts of climate change and, in the case of the livestock sector, one of the most important responses is the adjustment of feeding practices [51].

The ongoing application of animal management associated with the use of animal manure to fertilize pastureland occurs in a context marked by modernizing influences, promoted principally through extensionist government programs that encourage the use of technological packages to maximize agricultural productivity $[28,30]$. Nonetheless, our study shows that the assimilation of new praxis and/or hybridization are subject to a corpus based on observation, experimentation and evaluation of how the soil reacts to chemical fertilizers. This also reflects a kosmos that views the soil as a living entity. The corpus and the kosmos, integrated, influence the optimal choice for the fertilization of grasslands. In parallel, different studies have validated the use of animal manure to improve the soil's structure, physical condition, water retention, and fertility [52]. When mobilized by dung beetles, the presence of manure in pastureland is associated with greater soil fertility and indirect biological control of parasites in animals [53]. Research has also shown that the incorporation of animal manure is one of the main strategies of adaptation to climate change adopted by campesinos in different parts of the world $[54,55]$.

Out of the different types of livestock farming covered by our study, poultry is the most representative and is, moreover, a primarily women's space. This can be related to the paramount role that women, as the persons responsible for domestic tasks, care work, and the management of home gardens, play in the family's daily sustenance [56,57]. In this context, poultry farming takes place close to the home, without altering the productive axis formed by home-farmyard articulation. In animal management, this articulation is apparent in the use of ash from the kitchen to prevent external parasites in the poultry. This praxis is also seen among campesinos in Zimbabwe [14]. The greater prevalence of sheep farming over cattle farming appears to be related to the size of the farm which, as a result of processes of reduction and change in the structure of land ownership, restricts the raising of cattle $[16,23]$. Cattle farming appears to be linked to the possibility of access to the praxis of summer 
grazing, the mountains, or rented pastureland. In addition, the maintenance of the praxis of transhumance is associated with its productive, cultural, and symbolic value [58]. Changes in types of livestock production may also be a response to climate change. In this sense, a decrease in livestock production and changes in both the species farmed and the location of pastures are part of one of the main responses of indigenous peoples and local communities to climate change [51].

In the case of ethnoveterinary health management, we identify a corpus of more than 30 plant species with therapeutic properties. The categories of diseases and symptoms with the highest informant consensus factors (ICF) are wounds and parasites. A high ICF for the parasite category was also recorded on Colares Island, Brazil, where 56 plant species were identified [59]. Similarly, in Ethiopia's Ankober district, the highest ICFs among the 51 plant species identified were for gastrointestinal diseases and parasites [60]. In the foothills of the Himalayas in Pakistan where 126 plant species were recorded, the highest ICFs were for the categories of respiratory and reproductive illnesses and parasites [12]. High ICFs for common categories and, in this case, parasites reveal how, in different parts of the world, the knowledge and practices of campesinos and indigenous peoples are able to treat common ailments with the resources available locally.

In the ethnoveterinary health management corpus, the prevalence of native species can be attributed to knowledge accumulated since pre-Hispanic times. Their medicinal and spiritual effects have been subject to different processes of observation and experimentation, with the consequent development of a medicinal repertoire [22,32-34]. The assimilation of exotic species has served to diversify the local therapeutic heritage [61] and they are widely used by both Mapuche and nonMapuche campesinos [32-34]. These exotic species are also used for ethnoveterinary purposes by campesinos and indigenous communities in other parts of the world. For example, garlic (Allium sativum) is used by China's Buyi people to treat infections in goats and sheep [13]; in Canada, in horses with respiratory, infectious, and digestive problems [62]; and, in Austria and by China's Nu people, in cattle with parasites, reproductive disorders, fever, and diarrhea $[10,64]$.

This study found that only a small percentage of campesinos use TVM for health management. This can be attributed mainly to the adoption of allopathic medicine. Among the Maasai people of Africa, for example, the increasing use of allopathic medicine has also been identified as a cause of a decline in TVM use [65]. The case of Karamoja, Uganda, is different since limited access to allopathic medicine means that TVM predominates in the management of cattle health [66]. Other peoples also perceive changes in land use and climate change as threats. For example, in the Lesser Himalayas of Pakistan, the expansion of agricultural land is perceived as the main threat to the ongoing existence of plant species used in ethnoveterinary health management [12]. Similarly, in Nigeria, factors related to urbanization and climate change are reducing the availability of plant species for ethnoveterinary purposes to the detriment of their current and/or future use [67].

TVM serves to diversify health management options and it is, therefore, essential to validate the effectiveness of the different plant species. In this context, a social validation approach [68], the use of methods that combine participatory workshops and non-experimental validation (67), and in vitro and in vivo tests to determine therapeutic doses and toxicity levels (68) are alternatives for advancing in the safe and effective use of TVM.

\section{Conclusions}

Our results indicate the presence of diverse knowledge, practices, and beliefs about the traditional veterinary medicine (TVM) that is safeguarded by Mapuche and non-Mapuche campesinos in the southern Chilean Andes. Various processes of socioenvironmental change associated with agricultural modernization, reductions and changes in land ownership, and climate change are permeating ethnoveterinary knowledge, practices, and beliefs. This explains the persistence and/or loss of use of TVM as well as processes of assimilation of new practices and hybridization, indicating that TVM, far from being static, is constantly adapting. This study offers new perspectives that broaden the range of animal and health management alternatives for the development of bioculturally diverse livestock farming able, among other things, to navigate the current times of crisis. It is imperative to implement extensionist government programs that are culturally appropriate and respect and consider TVM in its different expressions, together with the promotion of sustainable and nature-friendly livestock praxis. In this context, advancing in TVM validation processes would facilitate the safe and effective use of therapeutic plant species.

Page $10 / 21$ 


\section{Declarations}

\section{Ethics approval and consent to participate}

Research approved by the Scientific Ethics Committee for the Social Sciences, Arts, and Humanities of the Catholic University of Chile. Number 190603004.

\section{Consent for publication}

Prior to interviews and the taking of pictures, each participant signed an informed letter of consent agreeing to publication of the results.

\section{Availability of data and materials}

To request materials related to this study, contact Fernanda Olivares (fernandaolivaresmd@gmail.com).

\section{Competing interests}

The authors declare that they have no competing interests.

\section{Funding}

This research was financed by ANID/Fondecyt Regular 1200291 "Resilience of small-scale farming across spatial scales: agrobiodiversity and local knowledge in Important Agricultural Heritage Sites in Chile". It also received support from ANID/REDES 190033, ANID-Chile Laboratorio Natural Andes del Sur de Chile LN 200007, the Center for Intercultural and Indigenous Research CIIR - ANID/FONDAP 15110006, the Center of Applied Ecology and Sustainability CAPES - ANID PIA/BASAL FB0002 and the Cape Horn International Center for Global Change Studies and Biocultural Conservation CHIC ANID PIA/BASAL PFB210018. F.O. received financing from Chile's National Research and Development Agency (ANID) / Scholarship Program / MAGISTER NACIONAL/2019 - 22191041. This article is based on a thesis for a Master's in Rural Development, Universidad Austral de Chile.

\section{Authors' contributions}

F.O: conceptualization, methodology, fieldwork, data analysis, and writing of manuscript; C.M: supervision, review and editing of manuscript; JTI: supervision, review and editing of manuscript, and securing funding. All the authors read and approved the final manuscript.

\section{Acknowledgments}

We want to thank the 48 women and 12 men from Curarrehue and Pucón, who disinterestedly participated in this research and shared their valuable knowledge with us. We would also like to thank Santiago Kaulen and Rocío Almuna for their support with the fieldwork.

\section{References}

1. Toledo VM, Stepp J, Wyndham F, Zarger R. Ethnoecology: A conceptual framework for the study of indigenous knowledge of nature. In: Ethnobiology and biocultural diversity: Proceedings of the 7th International Congress of Ethnobiology. 2002.

2. McCorkle CM. An introduction to ethnoveterinary research and development. J Ethnobiol. 1986;6:129-149.

3. Mathias-Mundy E. Of herbs and healers. ILEIA Newsletter for Low External Input and Sustainable Agriculture.1989;4: 20-22

4. Wanzala W, Zessin KH, Kyule NM, Baumann MP, Mathia E, Hassanali A. Ethnoveterinary medicine: a critical review of its evolution, perception, understanding and the way forward. Livestock Res Rural Dev. 2005;17:119 
5. Confessor MV, Mendonça LE, Mourão JS, Alves RR. Animals to heal animals: ethnoveterinary practices in semiarid region, northeastern Brazil. J Ethnobiol Ethnomed. 2009;5:1-9. doi:10.1186/1746-4269-5-37

6. Aziz MA, Khan AH, Pieroni A. Ethnoveterinary plants of Pakistan: a review. J Ethnobiol Ethnomed. 2020;16: 1-18. doi:10.1186/s13002-020-00369-1

7. Shen S, Qian J, Ren J. Ethnoveterinary plant remedies used by Nu people in NW Yunnan of China. J Ethnobiol Ethnomed. 2010;6:24. doi: 10.1186/1746-4269-6-24

8. Lans C, Khan TE, Martin Curran M, McCorkle CM. Ethnoveterinary Medicine: Potential Solutions for Large-Scale Problems? In: Wynn S G, Fougère B J, editors. Veterinary Herbal Medicine. 2007.p.17-32.

9. McGaw LJ, Famuyide IM, Khunoana ET, Aremu AO. Ethnoveterinary botanical medicine in South Africa: A review of research from the last decade (2009 to 2019). J Ethnopharmacol. 2020; 257.doi: 10.1016/j.jep.2020.112864

10. Vogl CR, Vogl-Lukasser B, Walkenhorst M. Local knowledge held by farmers in Eastern Tyrol (Austria) about the use of plants to maintain and improve animal health and welfare. J Ethnobiol Ethnomed.2016; 12:40. doi: 10.1186/s13002-0160104-0

11. Geerlings E, Perezgrovas R. Tsa'nel, estudio etnoveterinario sobre prácticas de manejo y medicina tradicional realizadas por pastoras Tzotziles. In: Perezgrovas R, editors. Antología sobre etnoveterinaria. Origen y evolución en Chiapas. Chiapas, México: Instituto de Estudios Indígenas, Universidad Autónoma de Chiapas.2014.p. 138-166.

12. Abbasi AM, Khan SM, Ahmad M, Khan MA, Quave CL, Pieroni A. Botanical ethnoveterinary therapies in three districts of the Lesser Himalayas of Pakistan. J Ethnobiol Ethnomed. 2013;9:84. doi: 10.1186/1746-4269-9-84

13. Xiong Y, Long C. An ethnoveterinary study on medicinal plants used by the Buyi people in Southwest Guizhou, China. J Ethnobiol Ethnomed. 2020;16:46. doi: 10.1186/s13002-020-00396-y

14. Nyahangare ET, Mvumi BM, Mutibvu T. Ethnoveterinary plants and practices used for ecto-parasite control in semi-arid smallholder farming areas of Zimbabwe. J Ethnobiol Ethnomed. 2015;11:30. doi: 10.1186/s13002-015-0006-6

15. Martínez G J, Jiménez-Escobar N D. Plantas de interés veterinario en la cultura campesina de la Sierra de Ancasti (Catamarca, Argentina). Bol Latinoam Caribe PL. 2017; 16:329-346

16. Bengoa, J. Historia del pueblo mapuche: (siglo XIX y XX). Sexta Edición. Santiago, Chile: LOM ediciones. 2000.

17. Melin M, Mansilla P, Royo M. Cartografía cultural del Wallmapu: Elementos para descolonizar el mapa en Territorio Mapuche. LOM Ediciones.2019.

18. Latcham R. Los animales domésticos de la América Precolombiana. Publicaciones del Museo de Etnología y Antropología, Santiago, Chile. 1992.

19. Torrejón F, Cisternas M. Alteraciones del paisaje ecológico araucano por la asimilación mapuche de la agroganadería hispano-mediterránea (siglos XVI y XVII). Rev Chil de Hist Nat. 2002;75:729-736. doi: 10.4067/s0716$078 \times 2002000400008$

20. de Moesbach E W. Lonco Pascual Coña Ñi Tuculpazugun. Testimonio de un Cacique Mapuche. Pehuen, Santiago, Chile. 2006.

21. Gay C. Usos y costumbres de los araucanos. Editorial Taurus. 2018.

22. de Möesbach E W. Botánica Indígena de Chile. Museo Chileno de Arte Precolombino, Editorial Andrés Bello, Santiago, Chile.1992.

23. Bengoa J. Mapuche, colonos y el Estado Nacional. Editorial Catalonia. Santiago, Chile. 2014.

24. Montalba R, Vieli L, Vallejos-Romero A, Zunino H, Vera L. Determinación de las fuerzas conductoras de la transformación ambiental de La Araucanía Chilena: El "paisaje cultural” como marco de análisis. Dialogo Andin. 2017;54:51-61. doi: 10.4067/S0719-26812017000300051

25. Faiguenbaum S. Toda una vida: Historia de INDAP y los campesinos (1962-2017). Ministerio de Agricultura, Gobierno de Chile. 2017.

26. Ramírez E, Furnano A, Berdegué J, Escobar G, Romero L. Evaluación de programas de INDAP. Informe editado en su versión final. 2014.

Page 12/21 
27. INDAP- Instituto de Desarrollo Agropecuario. Nueva plataforma de servicios. 2021. https://www.indap.gob.cl/serviciosindap/nueva-plataforma-de-servicios Accessed 20 Sept 2021.

28. Ibarra JT, Barreau A, Caviedes J, Pessa N, Urra R. Huertas familiares tradicionales y emergentes: biodiversidad, aprendizaje y soberanía desde la interculturalidad. In: Ibarra JT, Caviedes J, Barreau A, Pessa N, editores. Huertas familiares y comunitarias: cultivando soberanía alimentaria. Santiago, Chile: Ediciones Universidad Católica de Chile. 2019. p. 139-166.

29. Marchant C, Fuentes N, Kaulen S, Ibarra JT. Saberes locales en huertas de montaña del sur de los Andes: un refugio de memoria biocultural mapuche pewenche. Pirineos. 2020; 175:1-17. doi: 10.3989/pirineos.2020.175010

30. Marchant C, Fuentes N, Castet G. Huertas de montaña: prácticas agroecológicas en la agricultura familiar de La Araucanía andina. In: Ibarra JT, Caviedes J, Barreau A, Pessa N, editors. Huertas familiares y comunitarias: cultivando soberanía alimentaria. Santiago, Chile: Ediciones Universidad Católica de Chile. 2019. p. 139-166.

31. Fuentes N, Marchant C. ¿Contribuyen las prácticas agroecológicas a la sustentabilidad de la agricultura familiar de montaña? El caso de Curarrehue, región de la Araucanía, Chile. Cuadernos De Desarrollo Rural. 2016;13:35-66

32. Montecino S, Conejeros A. Mujeres Mapuches. El saber tradicional en la curación de enfermedades comunes. Serie Mujer y Salud 2. Centro de Estudios de la Mujer, Chile .1985.

33. Estomba D, Ladio A, Lozada M. Medicinal wild plant knowledge and gathering patterns in a Mapuche community from North-western Patagonia. J Ethnopharmacol. 2006; 103:109-19. doi: 10.1016/j.jep.2005.07.015

34. Molares S, Ladio A. Ethnobotanical review of the Mapuche medicinal flora: Use patterns on a regional scale. J Ethnopharmacol. 2009; 122:251-60. doi:10.1016/j.jep.2009.01.003

35. Torri MC. Medicinal plants used in Mapuche traditional medicine in Araucanía, Chile: Linking sociocultural and religious values with local heath practices. Compl Health Pract Rev. 2010; 15:132-48. doi: 10.1177/1533210110391077

36. Benítez G, González-Tejero MR, Molero-Mesa J. Knowledge of ethnoveterinary medicine in the Province of Granada, Andalusia, Spain. J Ethnopharmacol. 2012;139:249-439. doi: 10.1016/j.jep.2011.11.029

37. Toledo VM, Barrera-Bassols N. La Memoria Biocultural: la importancia ecológica de las sabidurias tradicionales. Icaria editorial. Barcelona, España. 2008.

38. INE- Instituto Nacional de Estadística. XIX Censo Nacional de Población y VIII de Vivienda o Censo de Población y Vivienda. Santiago, Chile. 2017.

39. Barreau A, Ibarra JT, Wyndham FS, Rojas A, Kozak RA. How Can We Teach Our Children if We Cannot Access the Forest? Generational Change in Mapuche Knowledge of Wild Edible Plants in Andean Temperate Ecosystems of Chile. J Ethnobiol. 2016; 36:412-432. doi: 10.2993/0278-0771-36.2.412

40. Creswell JW, Plano Clark VL. Designing and Conducting Mixed Methods Research. SAGE Publications. 2017.

41. de Albuquerque UP, Lucena RD, Lins Neto EDF. Selection of Research Participants. In: de Albuquerque UP, Cruz da Cunha LVF, Lucena RD, editors. Methods and Techniques Ethnobiology and Ethnoecology. 2010. p.1-13

42. Bernard HR. Research methods in anthropology: qualitative and quantitative approaches. 4th edition. Alta Mira Press. Oxford.2006.

43. Ibarra JT, Caviedes J, Altamirano TA, Urra R, Barreau A, Santana F. Social-ecological filters drive the functional diversity of beetles in homegardens of campesinos and migrants in the southern Andes. Sci Rep. 2021;11:1-14. doi: 10.1038/s41598021-91185-4

44. Braun V, Clarke V. Using thematic analysis in psychology. Qual Res Psychol. 2006;3:77-101. doi: 10.1191/1478088706qp063oa

45. Heinrich M, Ankli A, Frei B, Weimann C, Sticher O. Medicinal plants in Mexico: Healers' consensus and cultural importance. Soc Sci Med. 1998, 47:1859-1871. doi: 10.1016/S0277-9536(98)00181-6

46. Barreau, A. Narrating changing foodways: wild edible plant knowledge and traditional food systems in Mapuche lands of the Andean Temperate Forests, Chile. Master's thesis, Faculty of Forestry, University of British Columbia, Vancouver, Canada. 2014. 
47. Chihuailaf E. Recado confidencial a los chilenos. Santiago: Lom Ediciones. 1999.

48. Canclini N G. Culturas híbridas: Estrategias para entrar y salir de la modernidad. Mexico. 1992.

49. Eyssartier C, Ladio AH, Lozada M. Cultural transmission of traditional knowledge in two populations of North-western Patagonia. J Ethnobiol Ethnomed. 2008;4:25.doi: 10.1186/1746-4269-4-25

50. Reyes-García V, Aceituno-Mata L, Calvet-Mir L, Garnatje T, Gómez-Baggethun E, Lastra JJ, et al. Resilience of traditional knowledge systems: The case of agricultural knowledge in home gardens of the lberian Peninsula. Glob Environ Change. 2014; 24:223-231. doi: 10.1016/j.gloenvcha.2013.11.022

51. Schlingmann A, Graham S, Benyei P, Corbera E, Martinez Sanesteban I, Marelle A, et al. Global patterns of adaptation to climate change by Indigenous Peoples and local communities. A systematic review. Curr Opin Environ Sustain.2021; 51:55-64. doi: 10.1016/j.cosust.2021.03.002

52. Altieri M. Agroecología. Bases científicas para una agricultura sustentable. Montevideo, Uruguay: Editorial NordanComunidad. 1999.

53. González-Chang M. Escarabajos estercoleros nativos en Chile. Una revisión con énfasis en su ecología. Agro Sur. 2015;43:51-61.doi: 10.4206/agrosur.2015.v43n3-06

54. Altieri M, Nicholls C. Los impactos del cambio climático sobre las comunidades campesinas y agricultores tradicionales y sus repuestas adaptativas. Agroecología. 2008;3:7-24.

55. Nicholls Cl, Altieri MA. Bases agroecológicas para la adaptación de la agricultura al cambio climático. URJ. 2019;11:5561. doi: 10.22458/urj.v11i1.2322

56. Barreau A, Ibarra M. Mujeres mapuche y huertas andinas: espacios de fertilidad, soberanía y transmisión de saberes. In: Ibarra JT, Caviedes J, Barreau A, Pessa N, editors. Huertas familiares y comunitarias: cultivando soberanía alimentaria. Santiago, Chile: Ediciones Universidad Católica de Chile. 2019. p. 127-139.

57. Mellado M. ¡Eran raíces! Relaciones sociales en las huertas familiares mapuche del Lago Neltume, Panguipulli. Undergraduate thesis, Universidad Austral de Chile, Valdivia, Chile.2014.

58. Marchant C. La práctica trashumante pehuenche en la Araucanía andina: una forma de construir y habitar los territorios de montaña del sur de Chile. Rev geogr Norte Gd. 2019;74:187-206.

59. Ritter RA, Monteiro MVB, Monteiro FOB, Rodrigues ST, Soares ML, Silva JCR, et al. Ethnoveterinary knowledge and practices at Colares island, Pará state, eastern Amazon, Brazil. J Ethnopharmacol. 2012;144: 346-352. doi:

10.1016/j.jep.2012.09.018

60. Lulekal E, Asfaw Z, Kelbessa E, van Damme P. Ethnoveterinary plants of Ankober District, North Shewa Zone, Amhara Region, Ethiopia. J Ethnobiol Ethnomed. 2014;10:21. doi: 10.1186/1746-4269-10-21

61. de Albuquerque UP. Re-examining hypotheses concerning the use and knowledge of medicinal plants: A study in the Caatinga vegetation of NE Brazil. J Ethnobiol Ethnomed. 2006;2:30. doi: 10.1186/1746-4269-2-30

62. Lans C, Turner N, Brauer G, Lourenco G, Georges K. Ethnoveterinary medicines used for horses in Trinidad and in British Columbia, Canada.J Ethnobiol Ethnomed. 2006;2:31. doi: 10.1186/1746-4269-2-31

63. Jacob MO, Farah KO, Ekaya WN. Indigenous Knowledge: The Basis of the Maasai Ethnoveterinary Diagnostic Skills. J Hum Ecol. 2004;16:43-48 doi:10.1080/09709274.2004.11905714

64. Gradé JT, Tabuti JRS, van Damme P. Ethnoveterinary knowledge in pastoral Karamoja, Uganda. J Ethnopharmacol. 2009;122:273-293. doi: 10.1016/j.jep.2009.01.005

65. Lateef AA, Smart O, Toba SA, Olatunde PA. Medicinal plants used in ethnoveterinary practices in the Federal Capital Territory, North-Central Nigeria. J Med Plants Res. 2020;14:377-388. doi: 10.5897/jmpr2020.6975

66. Ghotge NS, Ramdas SR, Ashalata S, Mathur NP, Broome VG, Sanyasi Rao ML. A social approach to the validation of traditional veterinary remedies - The Anthra project. Trop Anim Health Prod. 2002; 34:121-143. doi:

10.1023/A:1014266106237

67. Lans C., Turner N, Khan T, Brauer G, Boepple W. Ethnoveterinary medicines used for ruminants in British Columbia, Canada. J Ethnobiol Ethnomed. 2007; 3:1-22. https://doi.org/10.1186/1746-4269-3-11

Page $14 / 21$ 
68. McGaw L, Eloff J. Methods for Evaluating Efficacy of Ethnoveterinary Medicinal Plants. In: Ethnoveterinary Botanical Medicine. 2010.p.1-21.

\section{Tables}

Table 1. Corpus and praxis of TVM by Mapuche and non-Mapuche campesinos, southern Chilean Andes. 


\begin{tabular}{|c|c|c|c|}
\hline \multicolumn{2}{|l|}{ Corpus } & \multicolumn{2}{|l|}{ Praxis } \\
\hline $\begin{array}{l}\text { Season } \\
\text { of year }\end{array}$ & Category & $\begin{array}{l}\text { Animal } \\
\text { management }\end{array}$ & Description \\
\hline \multirow{3}{*}{ Winter } & (AT) & $\begin{array}{l}\text { Supplementary } \\
\text { feeding }\end{array}$ & $\begin{array}{l}\text { Feeding animals with bales, concentrate, oats, bamboo (Chusquea spp.), and } \\
\text { palo trébol (Dasyphyllum diacanthoides) to supplement production deficit of }\end{array}$ \\
\hline & $(\mathrm{BIO})$ & & \\
\hline & $\begin{array}{l}\text { (AT) } \\
\text { (BIO) }\end{array}$ & Animal shelter & $\begin{array}{l}\text { The practice of providing shelter for animals in pens, sheds, pigsties, coops, and } \\
\text { trees. }\end{array}$ \\
\hline \multirow[t]{3}{*}{ Spring } & $\begin{array}{l}\text { (AT) } \\
\text { (BIO) }\end{array}$ & Calving & $\begin{array}{l}\text { Planning of calving for different species to reduce neonatal and postnatal } \\
\text { deaths associated with feed deficits and extreme weather conditions. The } \\
\text { organization of calving permits a supply of animal protein for consumption } \\
\text { and/or sale at different times of the year. }\end{array}$ \\
\hline & $\begin{array}{l}\text { (AT) } \\
\text { (BIO) }\end{array}$ & Shearing & $\begin{array}{l}\text { Planning of shearing before the trune (Acaena ovalifolia) and } \\
\text { pimpinela (Acaena pinnatifida) species go to seed in order to prevent these } \\
\text { seeds from sticking to the wool. }\end{array}$ \\
\hline & (AS)(AT) & Tail docking & $\begin{array}{l}\text { The tail docking of ewes to facilitate the mating and lambing of future breeding } \\
\text { ewes is carried out during the waning moon, which is associated with a } \\
\text { decrease in body fluids, preventing hemorrhages and facilitating the } \\
\text { coagulation of the cut. }\end{array}$ \\
\hline \multirow[t]{6}{*}{ Summer } & $\begin{array}{l}(\mathrm{AT}) \\
(\mathrm{LIT}) \\
(\mathrm{HID})\end{array}$ & $\begin{array}{l}\text { Cattle } \\
\text { transhumance }\end{array}$ & $\begin{array}{l}\text { The practice of transhumance in which cattle are moved to mountainous areas } \\
\text { from December to March for feeding and mating. }\end{array}$ \\
\hline & $(E G)$ & & \\
\hline & $\begin{array}{l}\text { (AT) } \\
\text { (BIO) }\end{array}$ & Fodder storage & $\begin{array}{l}\text { The practice of storing unbaled grass with salt in sheds. The salt prevents mice } \\
\text { from entering the shed where the pasture is kept. In addition, adding salt makes } \\
\text { the feed more palatable in the winter season. }\end{array}$ \\
\hline & (AT) & $\begin{array}{l}\text { Seed } \\
\text { harvesting }\end{array}$ & $\begin{array}{l}\text { The seeds of cat grass (Dactylis glomerata), clover (Trifolium spp), ryegrass } \\
\text { (Lolium spp), and meadow soft grass (Holcus lanatus) are selected and } \\
\text { harvested for grassland improvement. The seeds are harvested from the } \\
\text { grassland as well as from the sheds where fodder is stored. }\end{array}$ \\
\hline & (BIO) & $\begin{array}{l}\text { Ram } \\
\text { separation }\end{array}$ & $\begin{array}{l}\text { The ram is separated from the sheep flock in order to send the ewes to early } \\
\text { mating, scheduling lambing for a season with greater forage availability and } \\
\text { better weather conditions. }\end{array}$ \\
\hline & $(\mathrm{AS})(\mathrm{AT})$ & Castration & $\begin{array}{l}\text { The practice of removing the testicles of cattle destined to become steers or } \\
\text { bullocks and pigs reserved for fattening during a waning moon. }\end{array}$ \\
\hline Autumn & (AT) & Mating & $\begin{array}{l}\text { This practice consists of bringing together the previously separated rams with } \\
\text { the flock of ewes for mating in April and/or May. }\end{array}$ \\
\hline \multirow[t]{3}{*}{ Annual } & (BIO) & $\begin{array}{l}\text { Adding ash to } \\
\text { chicken coops }\end{array}$ & $\begin{array}{l}\text { The practice of using ash in chicken coops to control ectoparasites such as bed } \\
\text { bugs (Cimex lectularius) and red mites (Dermanyssus gallinae). }\end{array}$ \\
\hline & $\begin{array}{l}\text { (AT) } \\
\text { (BIO) }\end{array}$ & $\begin{array}{l}\text { Late release of } \\
\text { sheep }\end{array}$ & $\begin{array}{l}\text { The practice of releasing the flock of sheep confined in barns, sheds, and/or } \\
\text { pens after } 9 \text { am to prevent the animals from ingesting slugs (Deroceras } \\
\text { reticulatum), present in the apical zone of the pastures, which cause swelling } \\
\text { and death of the sheep. }\end{array}$ \\
\hline & $\begin{array}{l}(\mathrm{LIT}) \\
(\mathrm{BIO})\end{array}$ & $\begin{array}{l}\text { Fertilization } \\
\text { with animal } \\
\text { manure }\end{array}$ & $\begin{array}{l}\text { Incorporation of animal manure into the grassland for fertilization. There are } \\
\text { different methods such as: spreading and incorporating the fresh manure left } \\
\text { by the livestock when grazing; leaving the sheep manure to dry in sheds and } \\
\text { then incorporating it into the meadows; preparing a mixture of manure from } \\
\text { different animal species for incorporation into the meadows once it has dried; } \\
\text { and mixing animal manure with different organic waste. }\end{array}$ \\
\hline
\end{tabular}


Nomenclature: Knowledge categories: (AS): Astronomical; (AT): Atmospheric; (BIO): Biological; (EG): Eco-geographic; (HD): Hydrosphere; (LIT): Lithosphere.

Table 2. Ethnoveterinary plant species mentioned by Mapuche and non-Mapuche campesinos, southern Chilean Andes. 


\begin{tabular}{|c|c|c|c|c|c|c|c|c|}
\hline Scientific name & Local name & $\begin{array}{l}\text { Mapuche } \\
\text { name }\end{array}$ & Family & Origin ${ }^{1}$ & $\begin{array}{l}\text { Life } \\
\text { form² }\end{array}$ & $\begin{array}{l}\text { Use } \\
\text { form }{ }^{3}\end{array}$ & Species $^{4}$ & $\begin{array}{l}\text { Frequency } \\
5\end{array}$ \\
\hline Drimys winteri & Canelo & $\begin{array}{l}\text { Foye, } \\
\text { Foique }\end{array}$ & Winteraceae & $\mathrm{N}$ & $\mathrm{T}$ & $P ; I$ & $\mathrm{C}, \mathrm{H}, \mathrm{P}, \mathrm{S}$ & 24 \\
\hline $\begin{array}{l}\text { Juncus } \\
\text { procerus }\end{array}$ & $\begin{array}{l}\text { Hierba de la } \\
\text { vaca }\end{array}$ & & Juncaceae & $\mathrm{N}$ & $\mathrm{H}$ & $\mathrm{R}$ & C & 20 \\
\hline $\begin{array}{l}\text { Plantago } \\
\text { lanceolata }\end{array}$ & Siete venas & & Plantaginaceae & E & $\mathrm{H}$ & $\mathrm{I} ; \mathrm{W}$ & $\begin{array}{l}\text { C, G, H, } \\
\text { P, Pi, S }\end{array}$ & 10 \\
\hline $\begin{array}{l}\text { Acaena } \\
\text { ovalifolia }\end{array}$ & Trun, trune & & Rosaceae & $\mathrm{N}$ & $\mathrm{H}$ & $\mathrm{D}$ & C, S & 8 \\
\hline $\begin{array}{l}\text { Weinmannia } \\
\text { trichosperma }\end{array}$ & Palo santo & $\begin{array}{l}\text { Teñiu, } \\
\text { Maden }\end{array}$ & Cunoniaceae & $\mathrm{N}$ & $\mathrm{T}$ & $R ; D$ & $\mathrm{C}, \mathrm{S}$ & 7 \\
\hline $\begin{array}{l}\text { Cryptocarya } \\
\text { alba }\end{array}$ & Peumo & Pengu & Lauraceae & $\mathrm{N}$ & $\mathrm{T}$ & $P ; D$ & $\mathrm{C}, \mathrm{S}$ & 6 \\
\hline Lomatia hirsuta & Radal & $\begin{array}{l}\text { Radal, } \\
\text { Raral }\end{array}$ & Proteaceae & $\mathrm{N}$ & $\mathrm{T}$ & $\mathrm{D} ; \mathrm{R}$ & C, S & 6 \\
\hline Azara serrata & Corcolén & & Flacourtiaceae & $\mathrm{N}$ & $S$ & $\mathrm{I} ; \mathrm{P}$ & $\mathrm{C}, \mathrm{H}, \mathrm{S}$ & 5 \\
\hline $\begin{array}{l}\text { Buddleja } \\
\text { globosa }\end{array}$ & Matico & $\begin{array}{l}\text { Pañil, } \\
\text { Palguin }\end{array}$ & Scrophulariaceae & $\mathrm{N}$ & $S$ & W & $\begin{array}{l}\text { C, G, H, } \\
\text { P,Pi, S }\end{array}$ & 5 \\
\hline $\begin{array}{l}\text { Fragaria } x \\
\text { ananassa }\end{array}$ & Frutilla & & Rosaceae & $\mathrm{N}$ & $\mathrm{H}$ & $\mathrm{R}$ & C & 4 \\
\hline $\begin{array}{l}\text { Aristotelia } \\
\text { chilensis }\end{array}$ & Maqui & $\begin{array}{l}\text { Maki, } \\
\text { këlon }\end{array}$ & Elaeocarpaceae & $\mathrm{N}$ & $\mathrm{T}$ & $\begin{array}{l}\mathrm{D} ; \mathrm{I} ; \\
\mathrm{M}\end{array}$ & C & 4 \\
\hline $\begin{array}{l}\text { Chenopodium } \\
\text { quinoa }\end{array}$ & Quinoa & Quinwa & Amaranthaceae & $\mathrm{N}$ & $\mathrm{H}$ & I & $P$ & 4 \\
\hline $\begin{array}{l}\text { Caldcluvia } \\
\text { paniculata }\end{array}$ & Triaca & $\begin{array}{l}\text { Quiaca, } \\
\text { Mepua }\end{array}$ & Cunoniaceae & $\mathrm{N}$ & $\mathrm{T}$ & I; R & C, S & 4 \\
\hline $\begin{array}{l}\text { Alstroemeria } \\
\text { aurea }\end{array}$ & Liuto & & Alstroemeriaceae & $\mathrm{N}$ & $\mathrm{H}$ & $M$ & C & 2 \\
\hline $\begin{array}{l}\text { Myoschilos } \\
\text { oblongum }\end{array}$ & Orocoipo & & Santalaceae & $\mathrm{N}$ & S & $\mathrm{D}$ & C, S & 2 \\
\hline $\begin{array}{l}\text { Chenopodium } \\
\text { ambrosioides }\end{array}$ & Paico & & Chenopodiaceae & $\mathrm{N}$ & $\mathrm{H}$ & $\mathrm{D}$ & $S$ & 2 \\
\hline $\begin{array}{l}\text { Artemisia } \\
\text { absinthium }\end{array}$ & Ajenjo & & Asteraceae & $E$ & $\mathrm{H}$ & I & $\mathrm{H}$ & 1 \\
\hline $\begin{array}{l}\text { Capsicum an- } \\
\text { nuum }\end{array}$ & Ají & & Solanaceae & $E$ & $\mathrm{H}$ & I & $P$ & 1 \\
\hline Allium sativum & Ajo & & Liliaceae & $E$ & $\mathrm{H}$ & 1 & $P$ & 1 \\
\hline $\begin{array}{l}\text { Nothofagus } \\
\text { dombeyii }\end{array}$ & Coihue & Coihue & Fagaceae & $\mathrm{N}$ & $\mathrm{T}$ & $\mathrm{D}$ & C & 1 \\
\hline Mentha spicata & $\begin{array}{l}\text { Hierba } \\
\text { buena }\end{array}$ & & Lamiaceae & $E$ & $\mathrm{H}$ & $\mathrm{R}$ & C & 1 \\
\hline $\begin{array}{l}\text { Foeniculum } \\
\text { vulgare }\end{array}$ & Hinojo & & Apiaceae & $E$ & $\mathrm{H}$ & $\mathrm{D}$ & $S$ & 1 \\
\hline Laurus nobilis & $\begin{array}{l}\text { Laurel de } \\
\text { campo }\end{array}$ & & Lauraceae & $\mathrm{E}$ & $\mathrm{T}$ & I & $P$ & 1 \\
\hline
\end{tabular}




\begin{tabular}{|c|c|c|c|c|c|c|c|c|}
\hline $\begin{array}{l}\text { Helianthus } \\
\text { annuus }\end{array}$ & Maravilla & & Asteraceae & E & $\mathrm{H}$ & $P$ & $P$ & 1 \\
\hline $\begin{array}{l}\text { Gunnera } \\
\text { tinctoria }\end{array}$ & Nalca & Pangue & Gunneraceae & $\mathrm{N}$ & $\mathrm{H}$ & $\mathrm{R}$ & $\mathrm{C}$ & 1 \\
\hline $\begin{array}{l}\text { Embothrium } \\
\text { coccineum }\end{array}$ & Notro & & Proteaceae & $\mathrm{N}$ & $\mathrm{T}$ & E & C, S & 1 \\
\hline Ribes spp. & Parrilla & Mulul & Grossulariaceae & $\mathrm{N}$ & S & $M$ & $\mathrm{C}$ & 1 \\
\hline Chusquea spp. & $\begin{array}{l}\text { Quila, } \\
\text { coyocho }\end{array}$ & $\begin{array}{l}\text { Cüla, } \\
\text { colew }\end{array}$ & Poaceae & $\mathrm{N}$ & $S$ & $E$ & C, S & 1 \\
\hline $\begin{array}{l}\text { Quillaja } \\
\text { saponaria }\end{array}$ & Quillay & $\begin{array}{l}\text { Cüllai, } \\
\text { Quillay }\end{array}$ & Quillajaceae & $\mathrm{N}$ & $\mathrm{T}$ & I & $S$ & 1 \\
\hline $\begin{array}{l}\text { Quinchamalium } \\
\text { chilense }\end{array}$ & Quinchamalí & & Santalaceae & $\mathrm{N}$ & $\mathrm{H}$ & $\mathrm{D}$ & $\mathrm{C}$ & 1 \\
\hline
\end{tabular}

Nomenclature: ${ }^{1}$ Origin: $\mathrm{N}=$ Native; $\mathrm{E}=$ Exotic. ${ }^{2}$ Life form: $\mathrm{A}=$ Tree; $\mathrm{S}=\mathrm{Shrub} ; \mathrm{H}=$ Herb. ${ }^{3}$ Use form: $\mathrm{D}=\mathrm{Diarrhea}$; $\mathrm{W}=\mathrm{W}$ ounds; I=Infection; $\mathrm{M}=$ Mastitis; $\mathrm{P}=$ Parasites; $\mathrm{Q}=$ Eye disease; $\mathrm{R}=$ Retained afterbirth. ${ }^{4}$ Species: $\mathrm{C}=\mathrm{Cattle}$; $\mathrm{G}=\mathrm{Goats} ; \mathrm{H}=\mathrm{Horses} ; \mathrm{P}=$ Poultry; $\mathrm{Pi}=$ Pigs; $\mathrm{S}=$ Sheep. ${ }^{5}$ Frequency: Number of mentions of each plant species.

Table 3. Informant consensus factor (ICF) by animal disease category mentioned by Mapuche and non-Mapuche campesinos, southern Andes.

\begin{tabular}{llll} 
Disease/symptoms category & $\mathbf{N}^{\circ}$ of species used & $\mathbf{N}^{\circ}$ of reported uses & ICF value \\
\hline Infectious diseases & 11 & 17 & 0.38 \\
\hline Diarrhea & 10 & 25 & 0.63 \\
\hline Retention of placenta & 7 & 36 & 0.80 \\
\hline Mastitis & 3 & 4 & 0.33 \\
\hline Infectious diseases & 2 & 12 & 0.91 \\
\hline Parasites & 4 & 31 & 0.90 \\
\hline Eye disease & 2 & 2 & 0.00
\end{tabular}

\section{Figures}




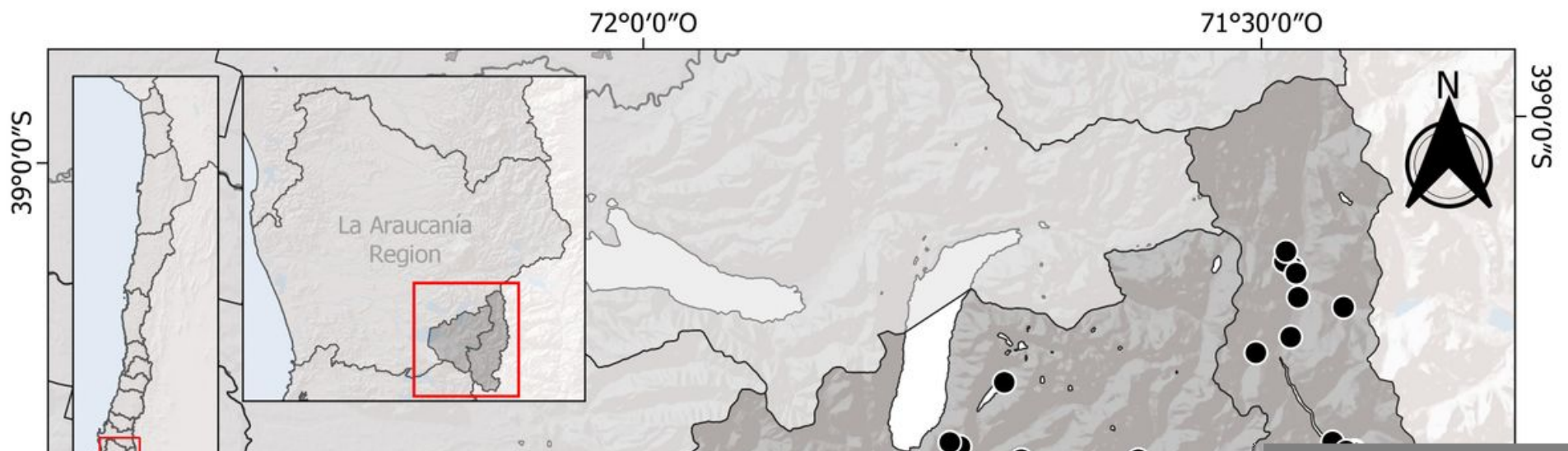

Figure 1

Study area in the Curarrehue and Pucón municipal districts, Araucanía Region, southern Chilean Andes. 


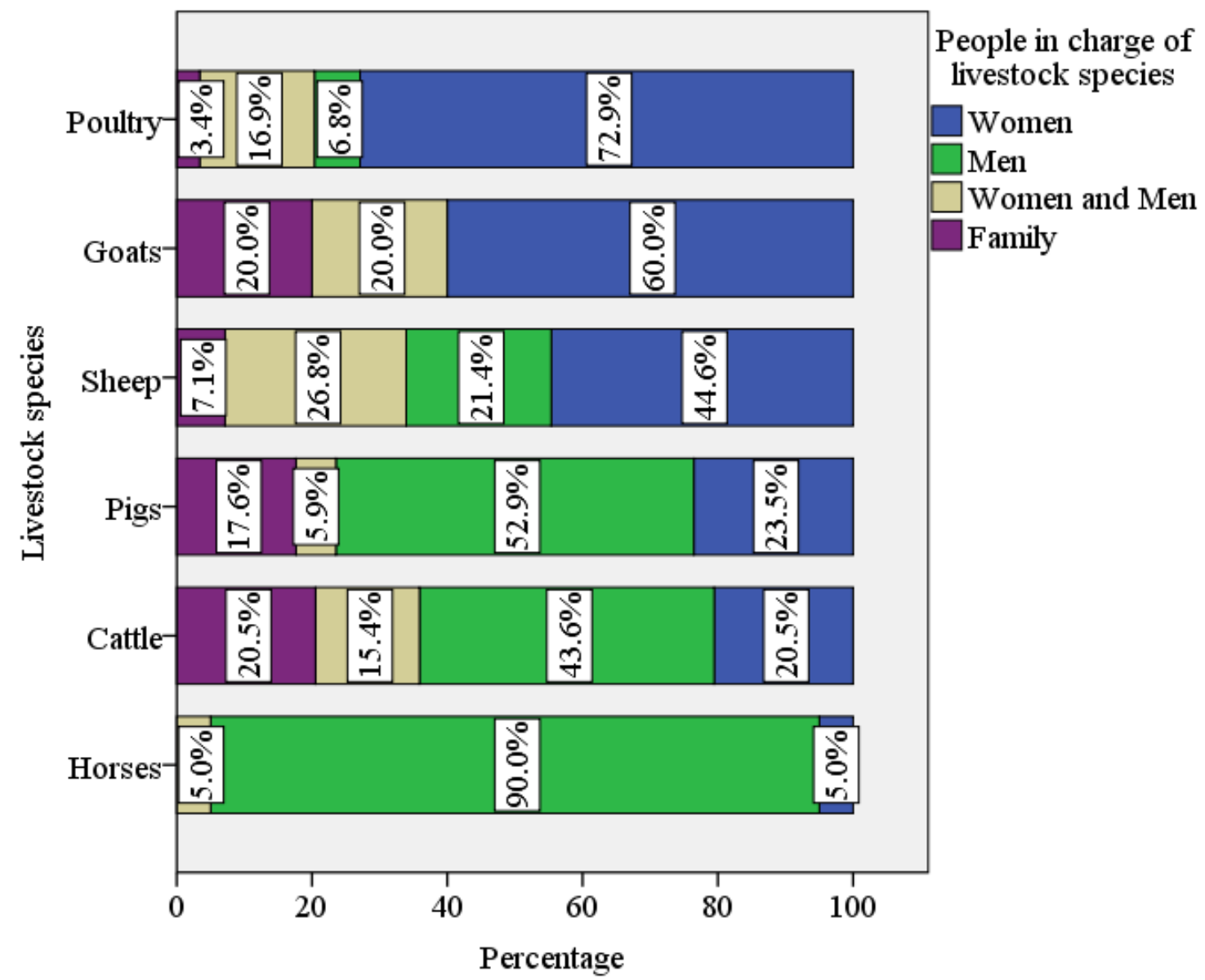

Figure 2

People in charge of different livestock species in the southern Chilean Andes.

Figure 3

Images showing (a) summer grazing area ("veranada"); (b) sheep flock next to rams. 